ECOLOGICA, Vol. 28, No 101 (2021), 134-141

https://doi.org/10.18485/ecologica.2021.28.101.20

Review article

UDC:338.48-6:502/504]:[616.98:578.834

\title{
The effects of Covid-19 pandemic on ecotourism
}

\section{Efekti pandemije Covid-19 na ekoturizam}

\author{
Saša Virijević Jovanović ${ }^{1}$, Duško Mlađenović ${ }^{2}$ Jelena Zdravković ${ }^{3}$ \\ ${ }^{1}$ Faculty of Applied Management, Economics and Finance, Belgrade, Serbia \\ ${ }^{1}$ Fakultet za primenjeni menadžment ekonomiju i finansije, Beograd, Srbija \\ 2Singidunum University, Belgrade, Serbia \\ 2Univerzitet Singidunum, Beograd, Srbija \\ ${ }^{3}$ Fourth Gymnasium, Belgrade, Serbia \\ ${ }^{3}$ Četvrta gimnazija, Beograd, Srbija
}

Rad primljen: 12.01.2021, Rad prihvaćen: 27.02.2021.

\begin{abstract}
The aim of this paper is to analyse the current research regarding the effects of coronavirus pandemic on ecotourism and particularly the wildlife tourism, in order to provide a significant cognitive basis that can be used for further studies. Literature review is applied as the most dominant scientific method in the paper. It was based on research studies dealing with different positive and negative effects in ecotourism that are directly or indirectly caused by the coronavirus outbreak. The main arguments in favour of positive impact of pandemic in tourism sector are concerning the environmental consequences that came as a result of limitations in human contacts and industrial activities. However, the majority of researchers recognised negative effects in ecotourism and wildlife protection, caused by reductions in income and employment.
\end{abstract}

Keywords: COVID-9, coronavirus pandemic, wildlife tourism, ecotourism, tourism.

Sažetak: Cilj ovog rada je da analizira trenutna istraživanja u vezi sa efektima pandemije koronavirusa na ekoturizam, a posebno na netaknute prirode, kako bi se obezbedila značajna kognitivna osnova koja se može koristiti za dalje studije. Pregled literature se primenjuje kao najdominantnija naučna metoda u radu. Baziran je na istraživačkim studijama koje se bave različitim pozitivnim i negativnim efektima u ekoturizmu koji su direktno ili indirektno uzrokovani izbijanjem koronavirusa. Glavni argumenti u prilog pozitivnog uticaja pandemije u turističkom sektoru odnose se na ekološke posledice koje su nastale kao rezultat ograničenja u ljudskim kontaktima i industrijskim aktivnostima. Međutim, većina istraživača prepoznala je negativne efekte u ekoturizmu i zaštiti netaknute prirode, prouzrokovane smanjenjem prihoda i zaposlenosti.

Ključne reči: COVID-9, pandemija koronavirusa, turizam netaknute prirode, ekoturizam, turizam.

${ }^{1}$ orcid.org/0000-0002-4469-381X, e-mail: sasa.virijevic@mef.edu.rs

2orcid.org/0000-0002-5196-1042, e-mail: duskommladjenovic@gmail.com

${ }^{3}$ orcid.org/0000-0002-3165-5101 


\section{INTRODUCTION}

The paper analyses the influence of coronavirus (COVID-19) pandemic on tourism and travel industry with special emphasis on ecotourism and wildlife tourism. As a result of the coronavirus pandemic the global travel and tourism industry found itself under the strongest impact. The statistic data confirm that this impact indicated numerous effects in tourism, regarding high employment loss in the sector (Lock, 2020 Aug), revenue decrease (Lock, 2020 Jun), as well as a significant drop in tourist arrivals and international flights (Lock, 2020 Apr). According to relevant statistical organisations the global revenue for the travel and tourism industry was estimated 396.37 billion U.S. dollars in 2020, which represents a decrease of 42.1 percent in compare to the previous year (Lock, 2020 Oct).

However, this paper analyses the effects of pandemic on ecotourism, as a type of tourism which is nature - based, sustainable and environmentally friendly. Therefore, ecotourism represents the opposite of mass tourism, and a solution to tourism problems such as environmental conservation, economic development, cultural preservation, poverty alleviation, etc. (Cobbinah, 2015).

Historically speaking, the term ecotourism originates from the early 1980s, when Hector CeballosLascuráin used this phrase for a concept, which he defined as 'traveling to relatively undisturbed or uncontaminated natural areas with the specific objective of studying, admiring, and enjoying the scenery and its wild plants and animals, as well as any existing cultural manifestations (both past and present) found in these areas (Ceballos-Lascurain, 1987). However, the relevance of environmentally effects of tourism are recognised earlier in the work of Hetzer, who identified four basic pillars that need to be respected in order to achieve responsible tourism. The pillars include: (1) minimum environmental impact; (2) minimum impact on - and maximum respect for - host cultures; (3) maximum economic benefits to the host country's grassroots; and (4) maximum "recreational" satisfaction to participating tourists. Furthermore, Hetzer considered responsible tourism as principally based upon natural and archaeological resources such as birds and other wildlife, scenic areas, reefs, caves, fossil sites, archaeological sites, wetlands, and areas of rare or endangered species (Hetzer, 1965).

According to available literature dealing with ecotourism, we can conclude that there was a confusion in the scientific public when it comes to defining this term. Authors cited different approaches to ecotourism, which arose from their views regarding the relations between ecotourism and the concepts of nature - based tourism (Valentine, 1993; Allcock et al., 1993; Wallace and Pierce, 1996) and sustainable tourism (Manning and Dougherty, 1995; Bjork, 2000) as well as different motives that drive tourists to travel (Bjork, 1995). In addition, some authors see ecotourism as a part of 'nature-based' tourism activities, while others consider it to be a 'niche' market, focused on a specific type of 'special interest tourism' (Wearing \& Neil, 2009, p.13). According to Duffy R. (2013) ecotourism is defined as nature-based tourism, which does not result in negative environmentally, economic and social impacts that are associated with mass tourism. Therefore, ecotourism involves cultural and environmental awareness, environmental conservation and empowerment of local communities and people, who provide resources important for ecotourism (Chafe, 2007; Virijević et al. 2020).

Recent definitions of ecotourism include education, as a significant element that defines the concept. Wearing and Neil recognise that ecotourism has an educative role $(2009, \mathrm{p} .12)$. In addition, Galley and Clifton notice that ecotourists are aware of nature-related issues and wish to learn about the environment (2004). Ramirez and Santana consider that education provided by ecotourism is a key factor for environmental conservation (2019).

In respect of these approaches Fennell (2015, p. 37-38) has recognised four core criteria for defining ecotourism. They refer to nature - based focus of ecotourism, sustainability in terms of local benefits and conservation, learning and the ethical imperative. Similar, UNWTO's definition of ecotourism includes the following characteristics:

- Nature based tourism, since the tourists are motivated to travel in order to observe the nature as well as the traditional cultures prevailing in natural areas;

- It has educative role;

- It is generally, but not exclusively organised by specialised tour operators for small groups;

- It minimises negative impacts on the natural and socio-cultural environment;

- It supports the maintenance of natural areas which are used as ecotourism attractions (UNWTO, 2002).

During the previous years ecotourism has become an important factor for developing rural communities while supporting the conservation of natural resources and cultural heritage. However, the coronavirus economic and humanitarian crisis has limited people's lives and travelling in general, which influenced the sector of ecotourism as well. Conse- 
quences of the coronavirus for ecotourism have been examined in this paper regarding their social, environmental and economic aspects (Nepal, 2020; Buckley, 2020; Pearson et al., 2020). According to Paxton (2020) the pandemic is affecting directly at least 100 million people who depend on the wildlife economy. Although it should be noted that research papers dealing with ecotourism during the pandemic are still limited due to the lack of data that need to be collected in the coming period. Therefore, future research on ecotourism during the COVID-19 lockdowns will provide new insights about its impact on the environment and wildlife.

\section{MATERIALS AND METHODS}

This paper combines current research studies and relevant statistic data in order to provide a cognitive basis and a commentary regarding the influence of COVID-19 on tourism and travel industry with special emphasis on ecotourism and wildlife tourism. Therefore, literature review is used as the most dominant scientific method in the paper. It was based on research studies dealing with different positive and negative effects in ecotourism that are directly or indirectly caused by COVID- 19 .

The starting points in this study were the assumptions that COVID -19 pandemic has influenced the sector of ecotourism, in two different ways. In one way the pandemic provided some positive effects on the environment, having in mind the fact that it changed human behaviour and reduced industrial activities worldwide. Therefore, in the context of ecotourism positive impacts are recognised as well. The current studies have particularly pointed out the importance of reduction in greenhouse gas emissions and air quality improvement (Buchholz, 2020), conservation of some endanger species (The Guardian, 2020; Gokkon, 2020) as well as minimising the effects of overtourism (Newsome, 2020). However, the majority of researchers demonstrated cases around the world, which confirm that the pandemic had negative impact on ecotourism (Badola, 2020; Somerville, 2020; Johanson, 2020; Poole, 2020; Faria, 2021; McNeely, 2021). Therefore, hypothetical framework of the research involved the following hypothesis.

H1: The pandemic of COVID-19 that limited human and industrial activities provided some positive effects on ecotourism in terms of pollution reduction and overtourism decline.

H2: The emergence of global coronavirus pandemic which demanded measures such as travel bans and lack of human contacts has negatively affected the sector of ecotourism, causing significant reduction in employment and income, which are essential factors that support development of local communities and wildlife protection.

\section{RESULTS AND DISCUSSION}

By analysing the current research and literature we have recognised two dominant effects of COVID19 pandemic on ecotourism and wildlife tourism, which can be classified as positive and negative. The main arguments in favour of positive impact of pandemic in tourism sector are concerning the environmental consequences that came as a result of limitations in human contacts and industrial activities. In particular, the lockdowns and reduction in transport and industrial functions led to significant decline in emissions such as carbon dioxide (statista, 2020). Positive influence on environment is also evidenced in cases of endanger spices which had benefits due to the lockdowns. Some examples include sea turtles in Florida (The Guardian, 2020a), shark and ray fishing in Indonesia (Gokkon, 2020) and bees in United Kingdom (The Guardian, 2020 b). Another benefit is seen from the perspective of overtourism decrease. The negative effects of overtourism and the inappropriate use of protected areas have been reduced since international bans on travel have been applied worldwide (Newsome, 2020).

When analysing negative influence of COVID19 on ecotourism the most dominant view is that travel bans and lack of human contacts, which caused the decrease in tourist arrivals, have also affected the income and employment in the sector.

Before the pandemic, wildlife tourism directly contributed 120.1 billion U.S. dollars in GDP to the global economy in 2018 which presents $4.4 \%$ of the global travel and tourism GDP (World Travel and Tourism Council -a, 2019). Findings in Figure 1 show the economic contribution of wildlife tourism in different continents in 2018. The greatest economic contribution is achieved in Asia - Pacific (53.3 billion U.S. dollars in GDP), followed by Africa (29,3 billion U.S. dollars in GDP).

There are numerous cases, which confirm the fact that well defined and managed ecotourism programs provide financial resources and employment in the community and give significant results in protecting animals and fragile ecosystems around the world (Libosada, 2009; Das \& Chatterjee, 2015). The example of fishermen in Philippines (Lowe, 2019), who decided to use the concept of ecotourism in order to protect endangered whale sharks presents a positive practice, showing the necessity of correlation between the tourist arrivals, fishermen engagement and the wildlife protection itself. Another good example of ecotourism we may 
find in the case of Namibia. The country has communal conservancies which are run by local residents, who benefit from wildlife management and tourism as well. The ecotourism projects in Namibia based on conservancies are in accordance with sustainable development, which is also evidenced in data showing that poaching activities in 2019 decreased by more than 60\% (UN, 2020). However, the emergence of COVID-19 with its effects on travel bans and health concerns has strongly affected the sector of ecotourism. The decrease in travel and tourist arrivals for subjects in ecotourism meant the decrease in income and employment as well. In Namibia it produced the loss of 3.2 million U.S. dollars in annual tourism revenue, and an additional 3.5 million U.S. dollars loss of salaries to staff living in conservancies (Paxton, 2020). In addition, East and Southern Africa safari industry, which generated 12 billion U.S. dollars in 2018, nowadays is facing negative consequences. According to findings presented in Figure 2, from November 2020 to January 2021, around 62.5 percent of safari tour operators reported having 75 percent or more of bookings cancelled (Faria, 2021).

\begin{tabular}{|c|c|c|c|c|c|c|}
\hline \multirow{2}{*}{ CONTINENT } & \multicolumn{4}{|c|}{ DIRECT } & \multicolumn{2}{|c|}{ TOTAL } \\
\hline & $\begin{array}{l}\text { DXPENDITURE } \\
\text { (\$ALON) }\end{array}$ & $\begin{array}{c}\text { GDP } \\
\text { (SBIIOW) }\end{array}$ & SHARE OF TRT & $\begin{array}{l}\text { EMPLOYMENT } \\
\text { (MILON) }\end{array}$ & $\begin{array}{c}\text { CDP } \\
\text { (SBUWOM) }\end{array}$ & $\begin{array}{l}\text { EMPLOYMENT } \\
\text { (MIWON) }\end{array}$ \\
\hline NORTH AMERICA & 25.4 & 13.5 & $2 \%$ & 0.2 & 37.6 & 0.5 \\
\hline EUROPE & 28.5 & 133 & $16 \%$ & 0.2 & 35.4 & 0.6 \\
\hline AFRICA & 48.8 & 29.3 & $36.3 \%$ & 3.6 & 70.6 & 8.8 \\
\hline ASIA-PACIFIC & 178.2 & 53.3 & $5.8 \%$ & 4.5 & 171.2 & 10.4 \\
\hline LATIN AMERICA & 19.9 & 10.7 & $8.6 \%$ & 0.5 & 28.9 & 14 \\
\hline TOTAL & 2410 & 120.1 & & 9.1 & 343.6 & 21.8 \\
\hline $\begin{array}{l}\text { SHARE OF TOTAL } \\
\text { GLOBAL T\&T (\%) }\end{array}$ & $4.2 \%$ & $4.4 \%$ & & $7.4 \%$ & $3.9 \%$ & $6.8 \%$ \\
\hline
\end{tabular}

Figure 1 - Economic contribution of wildlife tourism in 2018 (World Travel and Tourism Council - a, 2019)

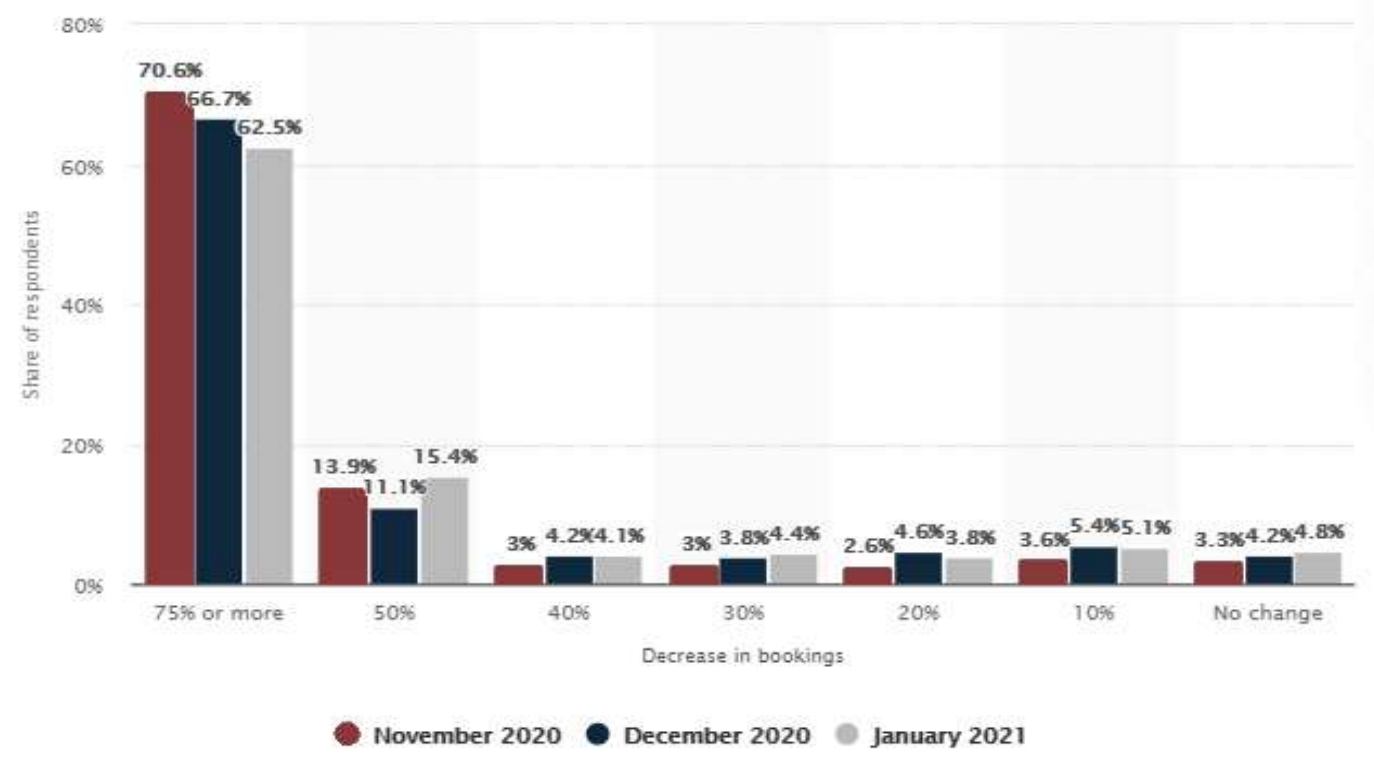

Figure 2 - Decrease in safari bookings due to coronavirus outbreak in Africa (Faria, 2021) 
Furthermore, wildlife conservation centres around the world are dealing with the problem of insufficient funding due to coronavirus pandemic. One of them is Elephant Conservation Centre (ECC) in Laos that take care about rescued Asian elephants. Around $85 \%$ of the centre's revenue is generated from paid visitors and so called "voluntourists", who pay $\$ 110$ per day for educational stays that involve no invasive riding or bathing with the animals (ECC, 2021). Therefore, the lack of tourists presents important problem that affects the functioning of the centre and the achievement of its main goal, which is the conservation of Asian elephants.

In wildlife tourism a loss of employment caused by COVID -19 is a significant issue. Before the pandemic, the sector of wildlife tourism generated 21.8 million jobs on global level. However it was especially vital in Africa (where it amounted $36.3 \%$ of the travel and tourism sector), Latin America (with the share of $8.6 \%$ ) and Asia-Pacific (where it made up $5.8 \%$ ) (WTTC - b, 2019). The loss of employment in wildlife tourism was particularly analysed from the perspective of rangers, since it created additional problems in controlling illegal fishing, poaching activity and protecting wildlife from human intrusion in general (Newsome, 2020; Vyawahare, 2020; Badola, 2020). Therefore, the pandemic is putting at risk some endanger species that have been protected through effective and innovative ecotourism programs. One of them is, for instance, in northern Cambodia, where unique endanger birds (giant ibises) were put under protection grace to the concept of ecotourism (Poole, 2020). However, during the pandemic, three giant ibises which present equivalent to $1-2 \%$ of the global population have been killed by the poachers (Alberts, 2020). Another difficulties happen with illegal logging and land clearing in countries with biodiversity-rich tropical forests (McNeely, 2021). For example the pandemic did not slow down the process of deforestation in the Brazilian Amazon. Instead, forest clearing in the Amazon increased 34\% in 2020 (Escobar, 2020). A rise in illegal logging is also registered in Nepal, including five parks with endangered Bengal tigers (World Wildlife Fund, 2020).

In addition, there are justified opinions that the pandemic is causing financial crisis, which is a great threat for biodiversity, particularly in some already fragile economic systems, where people are prepare to endanger the nature in search for money (Gardner, 2020). For instance, African species of rhinoceros, the Critically Endangered black (Diceros bicornis) and Near Threatened white (Ceratotherium simum), are being poached for their horns which are used in traditional Chinese medicine as a treatment (unproven) for the COVID-19 virus (Som- erville, 2020). An increase in poaching incidents was also recorded in India, where the cases involved illegal hunting of wild birds, leopards, desert antelopes and rhinos (Godbole, 2020), Colombia in the poaching of jaguars and pumas (Georgiou, 2020), South Africa and Botswana (Newburger, 2020).

Another concern that the pandemic has brought in the sector of ecotourism is related to the fact that the infection itself can be a high risk for some endanger species. According to recent studies, the northern white-cheeked gibbon, the Sumatran orangutan, and the western lowland gorilla - as well as the endangered chimpanzee and bonobo - are vulnerable to infection. The main reason for this are their genetic similarities to humans (Nicolaus, 2020). An additional problem lays in the fact that respiratory illnesses are already a significant cause of death in ape species (Negrey et al., 2018).

\section{CONCLUSION}

Considering different views and studies dealing with the effects of coronavirus pandemic on ecotourism and wildlife tourism it can be concluded that the majority of researchers presented negative consequences. Although, at the very beginning of the global pandemic, the public expected positive impact on the environment, due to reduction in transport and industrial activities, numerous examples and cases of ecotourism evidenced that the practice was quite the opposite. The outbreak of coronavirus put the sector of ecotourism at high risk by reducing the income and employment, which are crucial for the development of communities and wildlife protection. The loss of employment in wildlife tourism brought many problems in the sector such as difficulties in controlling illegal fishing and poaching activity, illegal logging and land clearing. Furthermore the lack of funding is a serious issue for many conservation centres, which have important role in sustainable development and wildlife protection. Another significant viewpoint considers the relation between financial crisis caused by coronavirus pandemic and human destructive, immoral, behaviour. This approach is based on different cases (India, Madagascar, Nepal) in which people are willing to act against the nature in search for income.

The paper analysed the current studies on ecotourism during the global coronavirus pandemic and presents limited findings due to the lack of data that need to be collected in the coming period in order to make further assumptions and conclusions. Therefore, some future research should include updated studies based on empirical scientific methods which will provide better insights in the effects of the pandemic on ecotourism. 


\section{REFERENCES}

[1] Alberts, E. C. (2020). Poachers kill 3 nearextinct giant ibises amid pandemic pressure in Cambodia. Mongabay, available at: https://news.mongabay.com/2020/04/poacher s-kill-3-near-extinct-giant-ibises-amidpandemic-pressure-in-cambodia/, (accessed 11 March 2021)

[2] Allcock, A., Jones, B., Lane, S., \& Grant, J. (1993). Draft National Ecotourism Strategy. Canberra: Commonwealth Department of Tourism.

[3] Badola, S. (2020). Indian wildlife amidst the COVID-19 crisis: An analysis of poaching and illegal wildlife trade. New Delhi: TRAFFIC, WWF - India

[4] Bjork, P. (2000). Ecotourism from a Conceptual Perspective, an Extended Definition of a Unique Tourism Form. International Journal of Tourism Research, 2, 189-202

[5] Buckley, R. (2020). Pandemic Travel Restrictions Provide a Test of Net Ecological Effects of Ecotourism and New Research Opportunities. Journal of Travel Research. August 2020.

[6] Buchholz, K. (2020). COVID-19 Improves Air Quality in Just Three Months. Published in April 24, https://www.statista.com/chart/21495/ no2-in-the-air-selected-cities/ (accessed 09 March 2021)

[7] Ceballos-Lascurain, H. (1987). Estudio de Prefactibilidad Socioconomica del Tourismo Ecologico y Anteproyecto Arquitectonico y Urbanistico del Centro de Tourismo Ecologico de Sian Ka'an Roo. Mexico City: SEDUE.

[8] Chafe, Z. (2007). Consumer demand for quality in ecotourism. In: Quality Assurance and Certification in Ecotourism (R. Black, \& A. Crabtree, eds). Worldwatch Institute, Washington, DC, pp. 164-95.

[9] Cobbinah, P.B. (2015). Contextualising the meaning of ecotourism. Tourism Management Perspectives, 16, 179-189.

[10] Das, M., \& Chatterjee, B. (2015). Ecotourism: a panacea or a predicament? Tourism Management Perspectives, 14, 3-16.

[11] Duffy, Rosaleen. (2013). A Trip Too Far: Ecotourism, Politics and Exploitation. London: Taylor and Francis

[12] Gardner, C. (2020). Nature's comeback? No, the coronavirus pandemic threatens the world's wildlife, available at: https://theconversation.com/naturescomeback-no-the-coronavirus-pandemic- threatens-the-worlds-wildlife-136209, (accessed 11 Mar 2021)

[13] Elephant Conservation Centre (2021), https://www.elephantconservationcenter.com/ our-work/, (accessed 09 Mar 2021)

[14] Escobar, H. (2020). Deforestation in the Brazilian Amazon is still rising sharply. Science, 369: 613.

[15] Faria, J. (2021). Impact of COVID-19 on safari bookings cancellations in Africa 2020-2021, Published online in January 18, https://www.statista.com/statistics/1150589/im pact-of-covid-19-on-safari-bookingscancellations-in-africa/, (accessed 09 March 2021)

[16] Fennell, D. A. (2015). Ecotourism. New York: Routledge

[17] Galley, G., \& Clifton, J. (2004) The motivational and demographic characteristics of research ecotourists: operation Wallacea volunteers in southeast Sulawesi, Indonesia. Journal of Ecotourism, 3(1), 69-82.

[18] Geogriou, A. (2020). Spike in Big Cat Poaching During Coronavirus Lockdown in Colombia, available at:

https://www.newsweek.com/spike-big-catpoaching-coronavirus-lockdown-colombiaconservation-group-1499783, (accessed 09 March 2021)

[19] Godbole, T. (2020). Coronavirus: South Asia sees rise in poaching during lockdowns, available at:

https://www.dw.com/en/coronavirus-southasia-sees-rise-in-poaching-duringlockdowns/a-54090081, (accessed 09 March 2021)

[20] Gokkon, B. (2020). As COVID-19 batters fishery, Indonesia's sharks get a respite. Mongabay Series: Indonesian Fisheries, available at: https://news.mongabay.com/2020/05/ascovid-19-response-batters-sales-indonesiasshark-fishery-gets-a-respite/, (accessed 09 March 2021)

[21] Hetzer, D. (1965). Environment, tourism, culture. Links, 1 (2), 1-3.

[22] Johanson, M. (2020). Tourism collapse puts wildlife conservation in peril. CNN Travel, Published online:

https://edition.cnn.com/travel/article/wildlifeconservation-struggles-pandemicscn/index.html, (accessed 09 March 2021)

[23] Libosada, C.M. (2009). Business or leisure? Economic development and resource protection concepts and practices in sustainable 
tourism. Ocean Coastal Management, 52, 390-394.

[24] Lock, S. (2020). COVID-19: job loss in travel and tourism sector worldwide 2020, by region. Published in Aug 21, https://www.statista.com/statistics/1104835/co ronavirus-travel-tourism-employment-loss/ (accessed 15 Feb 2021)

[25] Lock, S. (2020). Global change in travel and tourism revenue due to COVID-19 by region 2019-2020. Published online June 15 2020,

[26] Lock, S. (2020). Coronavirus: impact on the tourism industry worldwide - Statistics \& Facts. Published in April 9,

https://www.statista.com/topics/6224/covid-19impact-on-the-tourism-industry/

[27] Lock, S. (2020). Environmental effects of COVID-19, Published in Oct 20, https://www.statista.com/study/79011/environ mental-effects-of-covid-19/ (accessed 11 Mar 2021)

[28] Lowe, J. (2019). Poor Filipino fishermen are making millions protecting whale sharks, Published online: https:// theconversation.com/poor-filipino-fishermenare-making-millions-protecting-whale-sharks122451 (accessed March 9, 2021)

[29] Manning, E., \& Dougherty, D. (1995). Sustainable tourism: preserving the golden goose. Cornell Hotel and Restaurant Administration Quarterly, 36, 2, 29-41.

[30] McNeely, J.A. (2021). Nature and COVID-19: The pandemic, the environment, and the way ahead. Springer link, Ambio, available at: https://doi.org/10.1007/s13280-020-01447-0

[31] Nepal, S. K. (2020). Travel and Tourism after COVID-19: Business as Usual or Opportunity to Reset? Tourism Geographies. Published online May 2

[32] Negrey, J. D., Reddy, R. B., Scully, E. J., Phillips-Garcia, S., Owens, L.A., Langergraber, K. E., Mitani, J. C. , Thompson, M. E., Wrangham, R. W., Muller, M. N., Otali, E., Machanda,Z., Hyeroba, D., Grindle, K. A., Pappas, T. E., Palmenberg, A. C., Gern, J. E. \& Goldberg T. L. (2019). Simultaneous outbreaks of respiratory disease in wild chimpanzees caused by distinct viruses of human origin, Emerging Microbes \& Infections, 8:1, 139-149, DOI: $10.1080 / 22221751.2018 .1563456$

[33] Newsome, D. (2020). The collapse of tourism and its impact on wildlife tourism destinations. Emerald: Journal of Tourism Futures,
Published online June 15 2020,

https://www.emerald.com/insight/content/doi/1 0.1108/JTF-04-2020-0053/full/html, (accessed March 11, 2021).

[34] Newburger, E. (2020). Filthy bloody business: Poachers kill more animals as coronavirus crushes tourism to Africa, available at: https://www.cnbc.com/2020/04/24/coronavirus -poachers-kill-more-animals-as-tourism-toafrica-plummets.html, (accessed March 11, 2021)

[35] Nicolaus, P. (2020). Endangered primates face high risk of catching COVID-19. National Geographic, available at:

https://www.nationalgeographic.com/animals/ article/endangered-primates-face-high-risk-ofcatching-covid-19, (accessed March 11, 2021)

[36] Paxton, M. (2020). The coronavirus threat to wildlife tourism and conservation, UNDP, available at:

https://www.undp.org/content/undp/en/home/b log/2020/the-coronavirus-threat-to-wildlifetourism-and-conservation.html, (accessed March 11, 2021)

[37] Pearson, R. M., Sievers, M., McClure, E. C., Turschwell, M. P., Connolly, R. M. (2020). COVID-19 Recovery Can Benefit Biodiversity. Science, 368, 838-39.

[38] Poole, C. (2020). COVID-19 Threatens Endangered Species in Southeast Asia. Scientific American, available at:

https://blogs.scientificamerican.com/observati ons/covid-19-threatens-endangered-speciesin-southeast-asia/ (accessed 13 Feb 2021)

[39] Ramírez, F., Santana, J.C. (2019). Key lessons learned by teaching ecotourism to undergraduate students in Bogotá's urban wetlands, Applied Environmental Education \& Communication, 18 (3), 234-251

[40] Statista (2020). Forecasted change in revenue from the travel and tourism industry due to the coronavirus (COVID-19) pandemic worldwide from 2019 to 2020, available at:

https://www.statista.com/forecasts/1103426/c ovid-19-revenue-travel-tourism-industryforecast (accessed 13 Feb 2021)

[41] Somerville, K. (2020). COVID-19 increases the pressure: Botswana's rhino-poaching crisis. Global Geneva.

www.globalgeneva.com. (accessed 11 mar 2021)

[42] The Guardian (a) (2020). Florida: endangered sea turtles thriving thanks to Covid-19 restrictions, available at: 
https://www.theguardian.com/usnews/2020/apr/19/florida-leatherback-turtlescoronavirus-beaches (accessed 11 Mar 2021)

[43] The Guardian (b) (2020). Coronavirus may prove boost for UK's bees and rare wildflowers, available at:

https://www.theguardian.com/environment/20 20/apr/09/coronavirus-may-prove-boost-foruks-bees-and-rare-wildflowers, (accessed 11 Mar 2021)

[44] UNWTO (2002). The British Ecotourism Market

[45] UN (2020). Survival of wildlife reserves under threat in Namibia, available at:

https://www.un.org/en/coronavirus/survivalwildlife-reserves-under-threat-namibia, (accessed 11 Mar 2021)

[46] Valentine, P. (1993). Ecotourism and nature conservation. A definition with some recent developments in Micronesia. Tourism Management, 14 (2), 107-115.

[47] Virijević Jovanović, S., Doljanica, S. \& Janovac, T. (2020). Green economy in Iceland: an engine for tourism development. Ecologica, 27(100), 639-647.

[48] Vyawahare, M. (2020). National parks in Africa shutter over COVID-19 threat to great apes, available at: https://news.mongabay.com/ (accessed 15 Feb 2021)

[49] Wallace, G., \& Pierce, S. (1996). An evaluation of ecotourism in Amazonas, Brazil. Annals of Tourism Research, 23 (4), 843-873.

[50] World Travel and Tourism Council - a ( 2019). The economic impact of global wildlife tourism. Oxford Economics

[51] World Travel and Tourism Council - b (2019). Global wildlife tourism generates five times more revenue than illegal wildlife trade annually, Published online: https://wttc.org/NewsArticle/Global-wildlife-tourism-generates-fivetimes-more-revenue-than-illegal-wildlife-tradeannually, (accessed 10 Mar 2021)

[52] World Wildlife Fund (2020). Rising pressure on Nepal's tiger habitats amidst Covid-19, available at:

https://tigers.panda.org/news_and_stories/stor ies/rising_pressure_on_nepal, (accessed 10 Mar 2021)

[53] Wearing, S., \& Neil, J. (2009). Ecotourism: Impacts, Potentials and Possibilities? Oxford: Elsevier. 